\title{
Selection into shift work is influenced by educational attainment and body mass index: A \\ Mendelian randomization study
}

Iyas Daghlas $^{1,2}$, Rebecca C. Richmond ${ }^{3}$, Jacqueline M. Lane ${ }^{1,2,4}$, Hassan S. Dashti ${ }^{1,2,4}$, Hanna M. Ollila $^{1,2,5}$, Eva S. Schernhammer ${ }^{6,7}$, George Davey Smith ${ }^{3}$, Martin K. Rutter ${ }^{8,9}$, Richa Saxena ${ }^{1,2,4}$, Céline Vetter ${ }^{1,10}$

${ }^{1}$ Broad Institute of MIT and Harvard, 415 Main Street, Cambridge, MA, 02142, USA.

${ }^{2}$ Center for Genomic Medicine, Massachusetts General Hospital, 185 Cambridge Street, Boston, MA, 02114, USA.

${ }^{3}$ MRC Integrative Epidemiology Unit, Population Health Sciences, Bristol Medical School, University of Bristol,

Bristol, U.K.

${ }^{4}$ Anesthesia, Critical Care and Pain Medicine, Massachusetts General Hospital and Harvard Medical School, Boston, Massachusetts 02114, USA.

${ }^{5}$ Institute for Molecular Medicine Finland (FIMM), HiLIFE, University of Helsinki, Helsinki, Finland

${ }^{6}$ Channing Division of Network Medicine, Brigham and Women's Hospital and Harvard Medical School, Boston,

MA

${ }^{7}$ Department of Epidemiology, Center for Public Health, Medical University of Vienna, Vienna, Austria

${ }^{8}$ Division of Endocrinology, Diabetes and Gastroenterology, Faculty of Biology, Medicine and Health, School of Medical Sciences, University of Manchester, Manchester, U.K.

${ }^{9}$ Manchester Diabetes Centre, Central Manchester University Hospitals NHS Foundation Trust, Manchester Academic Health Science Centre, Manchester, U.K.

${ }^{10}$ Department of Integrative Physiology, University of Colorado at Boulder, Boulder, CO 80309-0354, USA.

Word count: 3,137 
medRxiv preprint doi: https://doi.org/10.1101/2020.03.10.20032698; this version posted March 19, 2020. The copyright holder for this preprint (which was not certified by peer review) is the author/funder, who has granted medRxiv a license to display the preprint in perpetuity.

\section{It is made available under a CC-BY-NC-ND 4.0 International license .}

\section{Correspondence}

Mr. Iyas Daghlas

Center for Genomic Medicine

Massachusetts General Hospital

185 Cambridge Street

Boston, MA 02114, US

Email: iyas_daghlas@hms.harvard.edu

Telephone: +1-573-823-3483

Dr. Céline Vetter

Department of Integrative Physiology,

University of Colorado at Boulder,

1725 Pleasant Street

Ramaley N368, 354 UCB,

Boulder, CO 80309-0354

Email: celine.vetter@colorado.edu

Telephone: +1-303-735-7377 
medRxiv preprint doi: https://doi.org/10.1101/2020.03.10.20032698; this version posted March 19, 2020. The copyright holder for this preprint (which was not certified by peer review) is the author/funder, who has granted medRxiv a license to display the preprint in perpetuity.

It is made available under a CC-BY-NC-ND 4.0 International license .

\begin{abstract}
Background: Shift work is associated with increased cardiometabolic disease risk, but whether this association is influenced by cardiometabolic risk factors driving selection into shift work is currently unclear. We addressed this question using Mendelian randomization (MR) in the UK Biobank.
\end{abstract}

Methods: We created genetic risk scores (GRS) associating with nine cardiometabolic risk factors (including education, body mass index [BMI], smoking, and alcohol consumption), and tested associations of each GRS with self-reported current frequency of shift work and night shift work amongst employed UKB participants of European ancestry $(n=190,573)$. We used summary-level MR sensitivity analyses and multivariable MR to probe robustness of the identified effects, and tested whether effects were mediated through sleep timing preference.

Results: Genetically instrumented lower educational attainment and higher body mass index increased odds of reporting frequent shift work (odds ratio [OR] per 3.6 years [1-SD] decrease in educational attainment $=2.40,95 \%$ confidence interval $[\mathrm{CI}]=2.22-2.59, \mathrm{p}=4.84 \times 10^{-20}$; OR per $4.7 \mathrm{~kg} / \mathrm{m}^{2}[1-\mathrm{SD}]$ increase in $\left.\mathrm{BMI}=1.30,95 \% \mathrm{CI}=1.14-1.47, \mathrm{p}=5.85 \times 10^{-05}\right)$. Results were unchanged in sensitivity analyses allowing for different assumptions regarding horizontal pleiotropy, and the effects of education and BMI were independent in multivariable MR. No causal effects were evident for the remaining factors, nor for any exposures on selection out of shift work. Sleep timing preference did not mediate any causal effects.

Conclusions: Educational attainment and BMI may influence selection into shift work, which may have implications for epidemiologic associations of shift work with cardiometabolic disease. 
medRxiv preprint doi: https://doi.org/10.1101/2020.03.10.20032698; this version posted March 19, 2020. The copyright holder for this preprint (which was not certified by peer review) is the author/funder, who has granted medRxiv a license to display the preprint in perpetuity.

It is made available under a CC-BY-NC-ND 4.0 International license.

\section{Key messages}

- Although it has been hypothesized that cardiometabolic risk factors and diseases may influence selection into shift work, little evidence for such an effect is currently available.

- Using Mendelian randomization, we assessed whether cardiometabolic risk factors and diseases influenced selection into or out of shift work in the UK Biobank.

- Our results were consistent with a causal effect of both higher BMI and lower educational attainment on selection into current shift work, with stronger effects seen for shift work that is more frequent and includes more night shifts.

- Using multivariable Mendelian randomization, we found that effects of higher BMI and lower education were independent. Sleep timing preference had a null effect on shift work selection and therefore did not mediate these effects.

- Selection through education and BMI may bias the relationship of shift work with cardiometabolic disease. Social mechanisms underlying these effects warrant further investigation. 
medRxiv preprint doi: https://doi.org/10.1101/2020.03.10.20032698; this version posted March 19, 2020. The copyright holder for this preprint (which was not certified by peer review) is the author/funder, who has granted medRxiv a license to display the preprint in perpetuity.

It is made available under a CC-BY-NC-ND 4.0 International license .

\section{Introduction}

Shift work is increasingly common and is a risk factor for cardiometabolic diseases ${ }^{1}$ including type 2 diabetes $(\mathrm{T} 2 \mathrm{D})^{2}$ and coronary artery disease $(\mathrm{CAD})^{3}$. In these studies the baseline characteristics of shift workers often systematically differ from non-shift workers, including: higher rates of smoking ${ }^{2,4,5}$, lower rates of alcohol consumption ${ }^{2,4}$, lower educational attainment ${ }^{6}$, and greater body mass index $(\mathrm{BMI})^{6-8}$. Such baseline differences may reflect either a selection effect $^{9}$ of these factors on shift work, a causal effect of shift work on these factors, or confounding by shared influences. To date, few studies have examined evidence for a potential selection effect ${ }^{10,11}$.

Clarifying which factors influence participation in shift work is of public health interest. First, identifying factors that influence selection into shift work would offer basic insights into which populations are at highest risk for working in unfavorable conditions ${ }^{12}$. Second, shift work may mediate the effects of cardiometabolic risk factors, such as lower educational attainment ${ }^{13}$, on adverse health outcomes. Alternatively, factors influencing selection into shift work may confound observational relationships between shift work and adverse health outcomes. Estimating the magnitude of this selection effect could facilitate development of methodology to better account for this confounding and improve our understanding of the adverse effects of shift work on health.

Observational data have limitations for identifying selection factors, due to timing of exposure measurement, unmeasured confounding, and effects of shift work on the risk factor (i.e. reverse causation). One method to overcome these limitations is Mendelian randomization (MR) ${ }^{14}$. MR 
medRxiv preprint doi: https://doi.org/10.1101/2020.03.10.20032698; this version posted March 19, 2020. The copyright holder for this preprint (which was not certified by peer review) is the author/funder, who has granted medRxiv a license to display the preprint in perpetuity.

It is made available under a CC-BY-NC-ND 4.0 International license .

uses genetic variants as proxies for epidemiologic exposures to estimate causal effects. This approach is well-suited for identifying selection effects on shift work because genetic variants are precisely measured and less prone to bias through confounding or reverse causality ${ }^{15,16}$.

Previous MR analyses supported a causal effect of BMI on lower income and socioeconomic status $^{12,17}$, but MR has not been applied to characterize the determinants of selection into shift work. We used MR to assess the causal effect of cardiometabolic risk factors and diseases on shiftwork selection in the UK Biobank ${ }^{18}$.

\section{Methods}

\section{Population}

The UK Biobank is a population-based cohort study that enrolled over 500,000 volunteers aged 40-69 from 2006-2010; participation rate: $5.5 \%^{18}$. Data collection included questionnaire and nurse interview information, anthropometric and physiological measurements, and genomic data as previously described ${ }^{18,19}$. All participants provided written informed consent, and data used in this study were de-identified.

\section{Exposures}

The exposures were single genetic variants or weighted genetic risk scores (GRS) derived from genome-wide association studies (GWAS) for cardiometabolic risk factors and diseases: alcohol consumption, smoking heaviness, body mass index (BMI), waist-to-hip ratio adjusted for BMI, type 2 diabetes, coronary artery disease, and educational attainment (Table 1$)^{20,21,22,23,24,13,25,26,27}$. We focused on risk factors with publicly available GWAS summary statistics, and with putative 
causal effects on cardiometabolic outcomes, as supported by prior MR studies ${ }^{13,20,28-31}$. A single nucleotide polymorphism (SNP) in the alcohol dehydrogenase 1B $(A D H 1 B)$ gene robustly associated with reduced alcohol consumption ${ }^{20}$ was used to proxy alcohol consumption. Consistent with previous analyses ${ }^{20}$, we coded this missense variant (rs 1229984) under a dominant model (cases combining homozygotes and heterozygotes), with the effect allele oriented to reduced alcohol consumption. A single missense variant (rs16969968) in the Cholinergic Receptor Nicotinic Alpha 5 Subunit (CHRNA5) gene, associated at genome-wide significance with one additional cigarette smoked per day ${ }^{21}$, was used as the genetic instrument for smoking heaviness (limiting the sample to ever smokers ${ }^{32}$ ). For all other exposures, we used SNP associations from GWAS meta-analyses that did not include UKB data to generate multiSNP GRS ${ }^{22,23,25,27}$. Figure 1 shows a causal diagram by which these exposures may influence shiftwork selection.

[Insert Figure 1 here]

We utilized risk profiling in PLINK ${ }^{33}$ v1.9 to construct beta-weighted GRS using individuallevel data in the UKB for participants of White British ancestry; weights were obtained from the respective GWAS. We regressed each GRS on the respective exposure to determine the strength of each genetic instrument, using an F-statistic >10 to indicate minimal influence of weak instrument bias $^{34}$.

\section{Outcomes}


medRxiv preprint doi: https://doi.org/10.1101/2020.03.10.20032698; this version posted March 19, 2020. The copyright holder for this preprint (which was not certified by peer review) is the author/funder, who has granted medRxiv a license to display the preprint in perpetuity.

It is made available under a CC-BY-NC-ND 4.0 International license .

We derived the study outcomes using current shift work characteristics at baseline from currently employed UKB participants. Participants were asked to indicate shift work participation by answering the following question: 'Does your work involve shift work?' defined as 'a work schedule that falls outside of the normal daytime working hours of 9am-5pm. This may involve working afternoons, evenings or nights or rotating through these kinds of shifts.' Response options included: 'never/rarely,' 'sometimes,' 'usually,' 'always,' 'prefer not to answer,' and 'do not know.' 'Never/rarely' served as the reference group, 'sometimes' was an intermediate group, and 'usually' and 'always' were collapsed into 'frequent shift work;' totaling three groups in this analysis. 'Prefer not to answer' and 'do not know' were coded as missing.

Participants indicating that they currently worked shifts were further queried, 'Does your work involve night shifts,' defined as 'a work schedule that involves working through the normal sleeping hours, for instance working through the hours from 12 am to 6am.' Response options were identical to those for the primary shift work question and coded analogously. In the night shift work analyses we compared employed individuals not participating in shift work (reference group) with individuals working 'shift work, but no night shift work,' 'some night shift work,' and 'frequent night shift work;' resulting in four groups in this analysis.

All UKB participants with email addresses $(n \sim 330,000)$ were invited to complete an online follow-up questionnaire on lifetime employment information. This questionnaire queried information on each job worked over the participant lifetime $(n=118,699)$. For each job, participants were asked 'Did you ever work shifts (day and/or night shifts) for this job?'. To determine whether associations generalized beyond current shiftwork participation, we used this 
medRxiv preprint doi: https://doi.org/10.1101/2020.03.10.20032698; this version posted March 19, 2020. The copyright holder for this preprint (which was not certified by peer review) is the author/funder, who has granted medRxiv a license to display the preprint in perpetuity.

It is made available under a CC-BY-NC-ND 4.0 International license .

variable to derive an outcome of lifetime history of shiftwork, regardless of current employment status ( $\mathrm{n}=83,133 ; 22,987$ ever shift workers / 60,146 never shift workers). To identify exposures influencing selection out of shift work, we tested the outcome of history of quitting shift work. Cases were defined as participants reporting working a shiftwork job and subsequently working a non-shift work job $(n=22,987 ; 14,584$ cases of participants who ever quit shift work / 8,403 controls who worked shifts and never quit) as shown in Figure 2.

[Insert Figure 2 here]

\section{Individual-level analyses}

We first tested the association of each GRS ${ }^{35}$ with categories of the shiftwork outcomes using multinomial or binomial logistic regression adjusted for age, sex, and the top ten principal components (PCs) of ancestry. We transformed the effects of binary exposures (GRS for CAD and T2DM) to reflect a doubling in the odds of the exposure on the odds of the outcome ${ }^{36}$ (i.e. the effect of lifelong increased risk for disease on shift work selection).

We then probed the robustness of results through a series of secondary and sensitivity analyses. In order to include individuals who previously worked a job with shifts, but would no longer be included in the "current shift work" analysis, we also tested associations with lifetime history of shiftwork participation. To identify exposures influencing selection out of shift work, we tested associations with history of leaving shiftwork. To assess the impact of population stratification ${ }^{37}$, we controlled for i) 40 PCs of ancestry, and ii) the 22 UK Biobank assessment centers. Prior work suggested sex differences in the causal effects of BMI on socioeconomic outcomes ${ }^{17}$, so we 
tested for GRS interactions with sex using a model with an interaction term. We used UKB job codes to stratify jobs as 'skilled' and 'unskilled', using the classification laid out in Howe et al' ${ }^{12}$, and tested for interactions of job skill with the GRS using a model with an interaction term. Finally, we expanded the alcohol consumption and smoking heaviness instruments to include SNPs identified in a recent large-scale meta-analysis ${ }^{38}$. We used GRS weights from summary statistics excluding $\mathrm{UKB}^{38}$. These instruments explain more variance in the exposures relative to the single SNP instruments, but may be at greater risk for pleiotropy due to the inclusion of multiple variants with uncharacterized function ${ }^{39}$.

\section{Summary-level MR analyses and sensitivity analyses}

Genetic associations may be explained by horizontal pleiotropy, which is when variants influence the outcome through paths independent of the exposure of interest. We therefore conducted summary-level MR analyses to further assess whether the genetic associations represented casual relationships. We first estimated causal effects using inverse-variance weighted (IVW) random-effects regression, which is robust to balanced pleiotropy ${ }^{40}$. As a global test for pleiotropy, we calculated Cochran's Q for heterogeneity. We then used the following pleiotropy-robust sensitivity analyses: MR Egger ${ }^{41}$, weighted median ${ }^{42}$, and MR-PRESSO ${ }^{43}$ regressions (see Supplementary methods 1). We used the estimate of the MR Egger model intercept to further assess for balanced horizontal pleiotropy. Due to low power ${ }^{44}$, this method is generally more appropriate for ruling pleiotropy in rather than ruling it out.

These analyses were implemented using the TwoSampleMR R package v0.4.22 $2^{45}$. 
For effects identified in univariable MR, we undertook summary-level multivariable MR $(\mathrm{MVMR})^{45}$ simultaneously controlling for each exposure using the TwoSampleMR software ${ }^{45}$.

We confirmed instrument strength using the $\mathrm{Q}_{\text {strength }}$ adapted for $\mathrm{MVMR}^{46}$. The $\mathrm{Q}_{\text {strength }}$ divided by the number of variants is analogous to the F statistic, with values $>10$ indicating minimal weak instrument bias. Prior MR analyses identified a nominal effect of greater BMI on earlier sleep timing preference so we tested for a causal effect of early sleep timing preference on selection into shift work using GWAS estimates that did not overlap with $\mathrm{UKB}^{47}$. We hypothesized that earlier sleep timing preference would be negatively associated with current shift work, reflecting a negative selection effect. We planned to test MVMR of the exposures and sleep timing preference only if the first-stage association of sleep timing preference with shift work demonstrated an effect.

\section{Statistical software}

Analyses were conducted using R version 3.5.0, including the TwoSampleMR ${ }^{45}$ and $\mathrm{MVMR}^{46}$ packages.

\section{Results}

\section{Individual level analyses}

[Insert Figure 3 here]

The median age of employed participants in the UKB was 53 years [IQR 47-59], and $49 \%$ were male. Shift workers were more likely to be male and report lower indicators of socioeconomic 
medRxiv preprint doi: https://doi.org/10.1101/2020.03.10.20032698; this version posted March 19, 2020. The copyright holder for this preprint (which was not certified by peer review) is the author/funder, who has granted medRxiv a license to display the preprint in perpetuity.

It is made available under a CC-BY-NC-ND 4.0 International license .

and health status (Table 2). Each GRS was strongly associated with the exposures (Supplementary Table 1).

Genetically predicted educational attainment increased odds of working some shift work (odds ratio per 1-standard deviation (SD) / 3.6y (OR) 1.32, 95\% confidence interval (CI) 1.10-1.59, $\left.\mathrm{p}=2.64 \times 10^{-03}\right)$, frequent shift work $\left(\mathrm{OR}=2.22,95 \% \mathrm{CI}=1.89-2.63, \mathrm{p}<2 \times 10^{-16}\right)$, and frequent night shift work (OR 2.94, 95\%CI=2.27-3.85, $\mathrm{p}<2 \times 10^{-16}$; Figure 4). (Figures 3-4). Genetically predicted BMI increased odds of working 'some' shift work (OR 1.21, 95\% CI 1.08-1.35, $\left.\mathrm{p}=9.20 \times 10^{-04}\right)$, 'frequent' shift work (OR 1.25, 95\% CI 1.14-1.38, $\left.\mathrm{p}=7.40 \times 10^{-06}\right)$, and frequent night shift work (OR 1.44, 95\% CI 1.23-1.68, p=4.00 × 10 ${ }^{-06}$; Figures 3-4).

[Insert Figure 4 here]

Both educational attainment (OR 1.40, 95\% CI 1.20-1.64, $\left.\mathrm{p}=2.68 \times 10^{-05}\right)$ and BMI (OR 1.17, 95\% CI 1.06-1.28, $\mathrm{p}=1.68 \times 10^{-03}$ ) increased the odds of working at least one shiftwork job across the life course (Supplementary Table 2). No other exposures associated with shift work participation (Figures 3-4). No exposures were associated with history of leaving shift work (Supplementary Table 3).

Secondary and sensitivity analyses in individual level analyses

The BMI and education GRS associations with shift work did not interact with sex or job skill classification. Additional adjustment for population stratification through controlling for 40 principal components and UKB assessment center did not influence the BMI or education effects 
medRxiv preprint doi: https://doi.org/10.1101/2020.03.10.20032698; this version posted March 19, 2020. The copyright holder for this preprint (which was not certified by peer review) is the author/funder, who has granted medRxiv a license to display the preprint in perpetuity.

It is made available under a CC-BY-NC-ND 4.0 International license .

(Supplementary Table 4). Results were similar when using an expanded GRS for alcohol consumption $(\mathrm{OR}=1.07,95 \% \mathrm{CI}=0.88-1.32, \mathrm{p}=0.50)$ and smoking heaviness $(\mathrm{OR}=1.03$, $95 \% \mathrm{CI}=1.00-1.05, \mathrm{p}=0.02)$ on the outcome of frequent shift work. There was no effect of genetic propensity to early sleep timing preference on frequent shift work (OR 0.99, 95\% CI 0.96-1.04, $\mathrm{p}=0.79$ ) or frequent night shift work (OR 0.96, 95\% CI 0.90-1.02, $\mathrm{p}=0.16$ ).

Summary-level MR analyses

[Insert Table 3 here]

We conducted summary-level MR analyses to estimate instrumental causal effects robust to horizontal pleiotropy. IVW random-effects models showed consistent effects of higher BMI (OR $1.30,95 \%$ CI $1.14-1.47, \mathrm{p}=5.58 \times 10^{-05}$ ) and lower educational attainment (OR 2.40, 95\% CI 2.222.59, $\mathrm{p}=4.84 \times 10^{-20}$ ) on shift work (Table 3). Four lines of evidence suggest that the observed effects were not explained by horizontal pleiotropy. First, there was minimal evidence of heterogeneity (Table 3). Second, similar MR effects were observed across the Egger and weighted median analyses (Table 3). Third, there was no evidence of unbalanced pleiotropy as estimated by the Egger intercepts for the effects of BMI (intercept=-0.004, $\mathrm{p}=0.37$ ) and of education (intercept $=0.015, \mathrm{p}=0.07$ ) on shift work, although this test is generally underpowered. Fourth, MR-PRESSO did not detect pleiotropic outlier SNPs.

We next turned to multivariable MR to assess the independence of exposure effects on shift work. The genetic instruments for educational attainment $\left(\mathrm{Q}_{\text {strength }}=2,407, \mathrm{~F}_{\text {adjusted }}=15.4\right)$ and BMI 
$\left(\mathrm{Q}_{\text {strength }}=4,393, \mathrm{~F}_{\text {adjusted }}=28\right)$ were conditionally strong in multivariable MR. The effects of BMI

$\left(\mathrm{OR}=1.18,95 \% \mathrm{CI}=1.08-1.31, \mathrm{p}=1.94 \times 10^{-03}\right)$ and of education $(\mathrm{OR}=2.56,95 \% \mathrm{CI}=2.12-3.13$, $\mathrm{p}=1.48 \times 10^{-23}$ ) on self-reported 'frequent' shift work were independent in MVMR.

\section{Discussion}

These analyses revealed a causal and independent effect of lower educational attainment and higher BMI on current and lifetime selection into shift work, particularly night shift work. These effects were not mediated by sleep timing preference. There was minimal evidence for selection through other tested exposures.

Our findings provide evidence for a causal effect of lower educational attainment and higher BMI, but not of other cardiometabolic risk factors, on selection into shift work within this population. The effect sizes were larger when shift work involved night shifts, and with increasing frequency of shift work, supporting a dose-dependent effect. Selection into shift work (including alcohol consumption, BMI, smoking, lipids, and glucose) by cardiometabolic risk factors has been evaluated in previous observational studies $(\mathrm{N} \sim 2,800){ }^{10,11}$. These studies identified an association of smoking with future participation in shift work, but not of other cardiometabolic traits. This contrasts with our results, where we did not identify strong evidence for an effect of smoking heaviness on shift work selection. Given the inverse effect of educational attainment on shift work, and the known effect of educational attainment on reduced smoking $^{30}$, it is possible that educational attainment confounded the previously observed relationship of smoking with shift work. Although shift workers typically report lower educational attainment ${ }^{6,48}$, prior work has not evaluated the role of educational attainment in shift 
medRxiv preprint doi: https://doi.org/10.1101/2020.03.10.20032698; this version posted March 19, 2020. The copyright holder for this preprint (which was not certified by peer review) is the author/funder, who has granted medRxiv a license to display the preprint in perpetuity.

It is made available under a CC-BY-NC-ND 4.0 International license .

work selection. Our findings suggest that this imbalance is driven by a causal effect of lower educational attainment on selection into shift work.

We observed a robust effect of higher BMI on shift work selection. This is in contrast to null associations in prior observational work ${ }^{10,11}$, There are several potential explanations for these differences. First, the observational estimates ${ }^{10,11}$ had wide confidence intervals, and could not exclude moderate effects of BMI on selection. Second, the influence of BMI on selection into shift work may accrue over time, such that effects are only observed later in life. Such a phenomenon would affect the present analysis, given the use of an older sample in contrast to the younger samples studied in prior studies of selection into shift work. However, this finding is consistent with the growing evidence for a causal effect of higher BMI on lower socioeconomic status $^{12,17}$.

There are several potential pathways by which education and BMI may influence selection into shift work. Lower educational attainment is related to lower-skilled employment ${ }^{49}$, which is generally more typical of shift work ${ }^{50}$. It is less clear what mediates the effect of BMI on selection into shift work. One potential mechanism is weight stigma, which is a highly prevalent $^{51}$, well-characterized driver of employment inequities ${ }^{52}$. Women experience a greater burden of this discrimination than $\operatorname{men}^{53}$, but we observed no interaction by sex, suggesting that men and women experience similar selection pressures into shift work on the basis of differences in adiposity and educational attainment. Although we hypothesized that differences in sleep timing preference due to variation in $\mathrm{BMI}^{47}$ or education may be a mediating mechanism, we did not observe an effect of earlier sleep timing preference on night shift odds. This is surprising 
given that night shift workers who tend to sleep earlier may experience the greatest burden of circadian misalignment ${ }^{54,55}$, and would therefore be more likely to select out of night shift work. A possible interpretation of this result is that selection effects of other social factors, such as socioeconomic status or educational attainment, preclude leaving a job on the basis of tolerability. We did not identify factors influencing selection out of shift work, but this sample was an order of magnitude smaller than the main sample, and we may have been underpowered to observe modest effects.

The present results have several potential implications for shift work research. The associations of shift work with cardiometabolic outcomes may be influenced by confounding by BMI and educational attainment. This does not invalidate the contribution of circadian misalignment to the excess disease risk conferred by shift work, but confounding may distort these estimates. Crosssectional studies of shift work using obesity as an outcome may be at high risk for bias, as any observed associations will reflect a sum of forward and reverse causal effects. ${ }^{56}$ Analyses restricted to shift workers may also be affected by collider bias ${ }^{57}$, which can induce false positive associations. Alternatively, shift work may mediate the effects of education and BMI on health outcomes. Recent MR mediation analyses showed that only half the variance of the effect of education on coronary artery disease risk is explained by conventional risk factors ${ }^{30}$, and shift work is an independent risk factor for cardiovascular disease ${ }^{3}$. Exposure to shift work may therefore explain part of the variance in this relationship. More broadly, MR may be a useful tool in occupational epidemiology to determine whether reverse causality may drive epidemiologic associations. 
Our study has some limitations. We studied shift work in a middle-older aged population, and our results may therefore not generalize to younger populations. Given that UKB is a relatively healthy population ${ }^{58}$, our results may not generalize to sicker populations and may not be applicable to other populations or cohorts ${ }^{59}$ with different occupation structures or ethnicities. Moreover, the identified effects may be driven by selection bias in UKB given a $5 \%$ responder rate in the cohort ${ }^{58}$. Factors influencing selection into UKB may induce collider bias ${ }^{57}$ and false positive associations of exposures with selection into shift work. While we did not examine mediation through job-related factors, such as tolerability or fatigue, we were able to examine sleep timing preference and it did not appear to mediate the observed effects. Finally, despite consistent results in sensitivity analyses, the MR effect estimates may be biased by horizontal pleiotropy due to effects of genetic instruments on pathways influencing the outcome independently of the studied exposures. Triangulating results with analyses leveraging other forms of natural experiments, such as educational reform in the $\mathrm{UK}^{60}$, will strengthen confidence in causality.

In conclusion, higher BMI and lower educational attainment influenced selection into shift work and night shift work, while no other cardiometabolic risk factors were associated with selection into or out of shift work.

\section{Acknowledgements}

This research has been conducted using the UK Biobank Resource (UK Biobank application number 6818). We would like to thank the participants and researchers from the UK Biobank who contributed or collected data. 


\section{Funding}

R01 DK105072 (Saxena, Dashti, Vetter), R21OH011052 (Schernhammer, Vetter), R01

DK107859 (Dashti, Saxena), R01DK102696 (Saxena), MGH Research Scholar Fund (Saxena),

Diabetes UK 17/0005700 (Rutter), The University of Manchester (Research Infrastructure Fund).

RCR and GDS are members of the MRC Integrative Epidemiology Unit at the University of

Bristol funded by the Medical Research Council (MM_UU_00011/1). RCR is a de Pass Vice

Chancellor's Research Fellow at the University of Bristol.

\section{Disclosures}

C.V., during the conduct of the study, received research support from the NIH, was a scientific advisory board member of Circadian Light Therapy Inc., and served as a paid consultant to the US Department of Energy outside the submitted work. 
medRxiv preprint doi: https://doi.org/10.1101/2020.03.10.20032698; this version posted March 19, 2020. The copyright holder for this preprint (which was not certified by peer review) is the author/funder, who has granted medRxiv a license to display the preprint in perpetuity.

\section{References}

1. Kantermann T, Juda M, Vetter C, Roenneberg T. Shift-work research: Where do we stand, where should we go? Sleep Biol Rhythms. 2010;8(2):95-105.

2. Vetter C, Dashti HS, Lane JM, et al. Night Shift Work, Genetic Risk, and Type 2 Diabetes in the UK Biobank. Diabetes Care. 2018;dc171933.

3. Vetter C, Devore EE, Wegrzyn LR, et al. Association Between Rotating Night Shift Work and Risk of Coronary Heart Disease Among Women. JAMA. 2016 Apr 26;315(16):172634.

4. Tamimi RM, Schernhammer ES, Eliassen AH, et al. Rotating Night-Shift Work and the Risk of Breast Cancer in the Nurses' Health Studies. Am J Epidemiol. 2017;186(5):532540.

5. Amelsvoort LGPM Van, Jansen NWH, Kant Ij. Smoking among shift workers: More than a confounding factor. Chronobiol Int. 2006;23(6):1105-1113.

6. Amelsvoort LGPM Van, Schouten EG, Kok FJ. Impact of one year of shift work on cardiovascular disease risk factors. J Occup Environ Med. 2004;46(7):699-706.

7. Ramin C, Devore EE, Wang W, Pierre-Paul J, Wegrzyn LR, Schernhammer ES. Night shift work at specific age ranges and chronic disease risk factors. Occup Environ Med. 2015;72(2):100-107.

8. Fujishiro K, Lividoti Hibert E, Schernhammer E, Rich-Edwards JW. Shift work, job strain and changes in the body mass index among women: A prospective study. Occup Environ Med. 2017;74(6):410-416.

9. Puttonen S, Viitasalo K, Härmä M. The relationship between current and former shift work and the metabolic syndrome. Scand J Work Environ Heal. 2012;38(4):343-348.

10. Yong M, Germann C, Lang S, Oberlinner C. Primary selection into shift work and change of cardiovascular risk profile. Scand J Work Environ Heal. 2015;41(3):259-267.

11. Nabe-Nielsen K, Garde AH, Tüchsen F, Hogh A, Diderichsen F. Cardiovascular risk factors and primary selection into shift work. Scand J Work Environ Health. 2008 Jun;34(3):206-212.

12. Howe LD, Kanayalal R, Harrison S, et al. Effects of body mass index on relationship status, social contact and socio-economic position: Mendelian randomization and withinsibling study in UK Biobank. Int J Epidemiol. 2019 Dec 4;524488.

13. Tillmann T, Vaucher J, Okbay A, et al. Education and coronary heart disease: Mendelian randomisation study. BMJ. 2017;358.

14. Davey Smith G, Ebrahim S. 'Mendelian randomization': can genetic epidemiology contribute to understanding environmental determinants of disease? Int J Epidemiol. 2003 Feb;32(1):1-22.

15. Smith GD, Lawlor DA, Harbord R, Timpson N, Day I, Ebrahim S. Clustered environments and randomized genes: a fundamental distinction between conventional and genetic epidemiology. PLoS Med. 2007;4(12):1985-1992.

16. Davies NM, Holmes M V., Davey Smith G. Reading Mendelian randomisation studies: A guide, glossary, and checklist for clinicians. BMJ. 2018;362.

17. Tyrrell J, Jones SE, Beaumont R, et al. Height, body mass index, and socioeconomic status: mendelian randomisation study in UK Biobank. BMJ. 2016 Mar 8;i582.

18. Bycroft C, Freeman C, Petkova D, et al. The UK Biobank resource with deep phenotyping and genomic data. Nature. 2018 Oct 10;562(7726):203-209. 
medRxiv preprint doi: https://doi.org/10.1101/2020.03.10.20032698; this version posted March 19, 2020. The copyright holder for this preprint (which was not certified by peer review) is the author/funder, who has granted medRxiv a license to display the preprint in perpetuity. It is made available under a CC-BY-NC-ND 4.0 International license .

19. Dashti HS, Jones SE, Wood AR, et al. Genome-wide association study identifies genetic loci for self-reported habitual sleep duration supported by accelerometer-derived estimates. Nat Commun. 2019 Dec 7;10(1):1100.

20. Holmes M V., Dale CE, Zuccolo L, et al. Association between alcohol and cardiovascular disease: Mendelian randomisation analysis based on individual participant data. BMJ. 2014 Jul 10;349(jul10 6):g4164-g4164.

21. The Tobacco and Genetics Consortium. Genome-wide meta-analyses identify multiple loci associated with smoking behavior. Nat Genet. 2010 May 25;42(5):441-447.

22. Locke AE, Kahali B, Berndt SI, et al. Genetic studies of body mass index yield new insights for obesity biology. Nature. 2015 Feb 12;518(7538):197-206.

23. Shungin D, Winkler TW, Croteau-Chonka DC, et al. New genetic loci link adipose and insulin biology to body fat distribution. Nature. 2015 Feb 12;518(7538):187-196.

24. Okbay A, Beauchamp JP, Fontana MA, et al. Genome-wide association study identifies 74 loci associated with educational attainment. Nature. 2016;533(7604):539-542.

25. Scott RA, Scott LJ, Mägi R, et al. An Expanded Genome-Wide Association Study of Type 2 Diabetes in Europeans. Diabetes. 2017 Nov;66(11):2888-2902.

26. Natarajan P, Young R, Stitziel NO, et al. Polygenic Risk Score Identifies Subgroup With Higher Burden of Atherosclerosis and Greater Relative Benefit From Statin Therapy in the Primary Prevention Setting. Circulation. 2017 May 30;135(22):2091-2101.

27. Nikpay M, Goel A, Won H-H, et al. A comprehensive 1,000 Genomes-based genomewide association meta-analysis of coronary artery disease. Nat Genet. 2015;47(10):112130 .

28. Lyall DM, Celis-Morales C, Ward J, et al. Association of Body Mass Index With Cardiometabolic Disease in the UK Biobank. JAMA Cardiol. 2017 Aug 1;2(8):882.

29. Emdin CA, Khera A V., Natarajan P, et al. Genetic Association of Waist-to-Hip Ratio With Cardiometabolic Traits, Type 2 Diabetes, and Coronary Heart Disease. JAMA. 2017 Feb 14;317(6):626.

30. Carter AR, Gill D, Davies NM, et al. Understanding the consequences of education inequality on cardiovascular disease: mendelian randomisation study. BMJ. 2019 May 22;11855.

31. Frayling TM, Stoneman CE. Mendelian randomisation in type 2 diabetes and coronary artery disease. Curr Opin Genet Dev. Elsevier Ltd; 2018;50:111-120.

32. Lassi G, Taylor AE, Timpson NJ, et al. The CHRNA5-A3-B4 Gene Cluster and Smoking: From Discovery to Therapeutics. Trends Neurosci. Elsevier Ltd; 2016;39(12):851-861.

33. Purcell S, Neale B, Todd-Brown K, et al. PLINK: A Tool Set for Whole-Genome Association and Population-Based Linkage Analyses. Am J Hum Genet. 2007 Sep;81(3):559-575.

34. Pierce BL, Ahsan H, Vanderweele TJ. Power and instrument strength requirements for Mendelian randomization studies using multiple genetic variants. Int J Epidemiol. 2011;40(3):740-752.

35. Burgess $\mathrm{S}$, Thompson SG. Use of allele scores as instrumental variables for Mendelian randomization. Int J Epidemiol. 2013;42(4):1134-1144.

36. Burgess S, Labrecque JA. Mendelian randomization with a binary exposure variable: interpretation and presentation of causal estimates. Eur J Epidemiol. Springer Netherlands; 2018;33(10):947-952. 
medRxiv preprint doi: https://doi.org/10.1101/2020.03.10.20032698; this version posted March 19, 2020. The copyright holder for this preprint (which was not certified by peer review) is the author/funder, who has granted medRxiv a license to display the preprint in perpetuity. It is made available under a CC-BY-NC-ND 4.0 International license .

37. Haworth S, Mitchell R, Corbin L, et al. Apparent latent structure within the UK Biobank sample has implications for epidemiological analysis. Nat Commun. Springer US; 2019 Dec 18;10(1):333.

38. Liu M, Jiang Y, Wedow R, et al. Association studies of up to 1.2 million individuals yield new insights into the genetic etiology of tobacco and alcohol use. Nat Genet. 2019;51(2):237-244.

39. Burgess S, Davey Smith G. How humans can contribute to Mendelian randomization analyses. Int J Epidemiol. 2019;1-4.

40. Bowden J, Del Greco M F, Minelli C, Davey Smith G, Sheehan N, Thompson J. A framework for the investigation of pleiotropy in two-sample summary data Mendelian randomization. Stat Med. 2017;36(11):1783-1802.

41. Bowden J, Smith GD, Burgess S. Mendelian randomization with invalid instruments: Effect estimation and bias detection through Egger regression. Int J Epidemiol. 2015;44(2):512-525.

42. Bowden J, Davey Smith G, Haycock PC, Burgess S. Consistent Estimation in Mendelian Randomization with Some Invalid Instruments Using a Weighted Median Estimator. Genet Epidemiol. 2016;40(4):304-314.

43. Verbanck M, Chen C-Y, Neale B, Do R. Detection of widespread horizontal pleiotropy in causal relationships inferred from Mendelian randomization between complex traits and diseases. Nat Genet. Springer US; 2018 May 23;50(5):693-698.

44. Guanghao Qi, Chatterjee N. A Comprehensive Evaluation of Methods for Mendelian Randomization Using Realistic Simulations of Genome-wide Association Studies. bioRxiv. 2019;

45. Hemani G, Zheng J, Elsworth B, et al. The MR-Base platform supports systematic causal inference across the human phenome. Elife. 2018;7:e34408.

46. Sanderson E, Davey Smith G, Windmeijer F, Bowden J. An examination of multivariable Mendelian randomization in the single-sample and two-sample summary data settings. Int J Epidemiol. 2019;48(3):713-727.

47. Jones SE, Lane JM, Wood AR, et al. Genome-wide association analyses of chronotype in 697,828 individuals provides insights into circadian rhythms. Nat Commun. Springer US; 2019 Dec 29;10(1):343.

48. Papantoniou K, Speizer F, Strohmaier S, et al. Rotating night shift work and colorectal cancer risk in the nurses' health studies. Int J Cancer. 2018;143(11):2709-2717.

49. Dieckhoff M. Skills and occupational attainment: A comparative study of Germany, Denmark and the UK. Work Employ Soc. 2008;22(1):89-108.

50. Jirjahn U. On the determinants of shift work and overtime work: Evidence from German establishment data. Br J Ind Relations. 2008;46(1):133-168.

51. Andreyeva T, Puhl RM, Brownell KD. Changes in perceived weight discrimination among Americans, 1995-1996 through 2004-2006. Obesity. 2008;16(5):1129-1134.

52. Puhl RM, Heuer CA. The Stigma of Obesity: A Review and Update. Obesity. 2009;17(5):941-964.

53. Roehling M V., Roehling P V., Pichler S. The relationship between body weight and perceived weight-related employment discrimination: The role of sex and race. $J$ Vocat Behav. 2007;71(2):300-318.

54. Vetter C, Fischer D, Matera JL, Roenneberg T. Aligning work and circadian time in shift workers improves sleep and reduces circadian disruption. Curr Biol. 2015;25(7):907-911. 
medRxiv preprint doi: https://doi.org/10.1101/2020.03.10.20032698; this version posted March 19, 2020. The copyright holder for this preprint (which was not certified by peer review) is the author/funder, who has granted medRxiv a license to display the preprint in perpetuity. It is made available under a CC-BY-NC-ND 4.0 International license .

55. Juda M, Vetter C, Roenneberg T. Chronotype modulates sleep duration, sleep quality, and social jet lag in shift-workers. J Biol Rhythms. 2013;28(2):141-151.

56. Sun M, Feng W, Wang F, et al. Meta-analysis on shift work and risks of specific obesity types. Obes Rev. 2018;19(1):28-40.

57. Munafò MR, Tilling K, Taylor AE, Evans DM, Smith GD. Collider scope: When selection bias can substantially influence observed associations. Int J Epidemiol. 2018;47(1):226235.

58. Fry A, Littlejohns TJ, Sudlow C, et al. Comparison of Sociodemographic and HealthRelated Characteristics of UK Biobank Participants With Those of the General Population. Am J Epidemiol. 2017 Nov 1;186(9):1026-1034.

59. Wang XS, Travis RC, Reeves G, et al. Characteristics of the million women study participants who have and have not worked at night. Scand J Work Environ Heal. 2012;38(6):590-599.

60. Barcellos SH, Carvalho LS, Turley P. Education can reduce health differences related to genetic risk of obesity. Proc Natl Acad Sci U S A. 2018;115(42):E9765-E9772. 
medRxiv preprint doi: https://doi.org/10.1101/2020.03.10.20032698; this version posted March 19, 2020. The copyright holder for this preprint (which was not certified by peer review) is the author/funder, who has granted medRxiv a license to display the preprint in perpetuity.

It is made available under a CC-BY-NC-ND 4.0 International license.

Table 1. Sources of SNP-exposure associations for genetic risk scores.

\begin{tabular}{|c|c|c|c|}
\hline Exposure & $\begin{array}{c}\text { Author/consortium name } \\
\text { (Pubmed ID) }\end{array}$ & n SNPs & Phenotype units in GWAS \\
\hline $\begin{array}{l}\text { Alcohol consumption - } \\
\text { primary analysis }\end{array}$ & $\begin{array}{c}\text { Holmes } \\
(25011450)\end{array}$ & 1 & $\begin{array}{l}17 \% \text { less weekly intake } \\
\text { volume }\end{array}$ \\
\hline $\begin{array}{l}\text { Alcohol consumption - } \\
\text { secondary analysis }\end{array}$ & $\begin{array}{c}\text { GSCAN } \\
(30643251)\end{array}$ & 89 & $\begin{array}{l}\text { Log-transformed drinks per } \\
\text { week }\end{array}$ \\
\hline $\begin{array}{l}\text { Smoking heaviness - } \\
\text { primary }\end{array}$ & $\begin{array}{l}\text { TAG consortium } \\
\text { (20418890) }\end{array}$ & 1 & 1 cigarette/effect allele \\
\hline $\begin{array}{l}\text { Smoking heaviness - } \\
\text { secondary analysis }\end{array}$ & $\begin{array}{c}\text { GSCAN } \\
(30643251)\end{array}$ & 45 & Binned cigarettes / day \\
\hline Body mass index & $\begin{array}{c}\text { GIANT } \\
(25673413)\end{array}$ & 91 & $1 \mathrm{SD}$ unit increase in $\mathrm{BMI}$ \\
\hline $\begin{array}{l}\text { Waist-hip-ratio } \\
\text { adjusted for BMI }\end{array}$ & $\begin{array}{c}\text { GIANT } \\
(25673412)\end{array}$ & 47 & $\begin{array}{l}1 \text { SD unit increase in } \\
\text { WHRadjBMI }\end{array}$ \\
\hline Type 2 diabetes & $\begin{array}{l}\text { DIAGRAM } \\
(28566273)\end{array}$ & 103 & Log-odds of diabetes \\
\hline $\begin{array}{l}\text { Coronary artery } \\
\text { disease }\end{array}$ & $\begin{array}{l}\text { CARDIoGRAMplusC4D } \\
\text { (26343387) }\end{array}$ & 57 & Log-odds of CAD \\
\hline $\begin{array}{l}\text { Educational } \\
\text { attainment }\end{array}$ & $\begin{array}{c}\text { SSGAC } \\
(27225129)\end{array}$ & 68 & $\begin{array}{l}1 \mathrm{SD} \text { increase in years of } \\
\text { schooling completed }\end{array}$ \\
\hline $\begin{array}{l}\text { Sleep timing } \\
\text { preference }\end{array}$ & $\begin{array}{l}\text { Jones, 23andme estimates } \\
\text { (30696823) }\end{array}$ & 331 & Log-odds of morningness \\
\hline
\end{tabular}


medRxiv preprint doi: https://doi.org/10.1101/2020.03.10.20032698; this version posted March 19, 2020. The copyright holder for this preprint (which was not certified by peer review) is the author/funder, who has granted medRxiv a license to display the preprint in perpetuity.

It is made available under a CC-BY-NC-ND 4.0 International license .

Table 2. Sample characteristics by current shift work status $(n=190,569)$. Summary statistics are shown as mean (standard deviation) or count (percentage).

\begin{tabular}{|c|c|c|c|}
\hline Exposure or covariate & $\begin{array}{c}\text { Employed, not } \\
\text { shift worker } \\
(n=159,900)\end{array}$ & $\begin{array}{c}\text { Some shift work } \\
(n=13,411)\end{array}$ & $\begin{array}{c}\text { Frequent shift work } \\
(n=17,258)\end{array}$ \\
\hline Age (years) & $53.13(7.08)$ & $52.34(7.00)$ & $51.94(6.87)$ \\
\hline Male sex $(\%)$ & $75794(47.4)$ & $7477(55.8)$ & $9692(56.2)$ \\
\hline Household income $<18,000(\%)$ & $12898(8.9)$ & $1496(12.4)$ & $2295(14.7)$ \\
\hline Household income $>100,000(\%)$ & $12056(8.3)$ & $641(5.3)$ & $268(1.7)$ \\
\hline University education & $63824(39.9)$ & $3749(28.0)$ & $2433(14.1)$ \\
\hline Years of education & $16.01(4.70)$ & $15.40(4.82)$ & $14.55(4.78)$ \\
\hline Townsend deprivation index & $-1.72(2.79)$ & $-1.10(3.06)$ & $-0.83(3.12)$ \\
\hline Lives with spouse or partner (\%) & $121599(83.3)$ & $9486(79.6)$ & $11844(77.9)$ \\
\hline Current smoker $(\%)$ & $15002(9.4)$ & $1928(14.4)$ & $2745(16.0)$ \\
\hline $\begin{array}{l}\text { Drinks per week (standardized } \\
\text { alcohol units) }\end{array}$ & $15.78(16.02)$ & $16.49(17.32)$ & $14.61(16.61)$ \\
\hline $\mathrm{BMI}\left(\mathrm{kg} / \mathrm{m}^{2}\right)$ & $27.08(4.62)$ & $27.94(4.89)$ & $28.14(4.91)$ \\
\hline Waist-hip-ratio & $0.86(0.09)$ & $0.88(0.09)$ & $0.89(0.09)$ \\
\hline $\mathrm{LDL}(\mathrm{mmol} / \mathrm{L})$ & $3.67(0.82)$ & $3.70(0.85)$ & $3.68(0.83)$ \\
\hline Coronary artery disease $(\%)$ & $2130(1.3)$ & $227(1.7)$ & $289(1.7)$ \\
\hline Type 2 diabetes $(\%)$ & $3757(2.3)$ & $379(2.8)$ & $529(3.1)$ \\
\hline $\begin{array}{l}\text { Early sleep timing preference } \\
\qquad(\%)^{1}\end{array}$ & $36,572(25.5)$ & $3,230(26.9)$ & $3,823(25.1)$ \\
\hline Excellent self-rated health $(\%)^{2}$ & $31588(19.8)$ & $2019(15.1)$ & $2356(13.7)$ \\
\hline Poor self-rated health $(\%)^{2}$ & $3084(1.9)$ & $336(2.5)$ & $544(3.2)$ \\
\hline
\end{tabular}

${ }^{1}$ Scale for sleep timing preference includes: "Definitely a 'morning' person," "More a 'morning' than 'evening' person," "More an 'evening' than a 'morning' person," and "Definitely an 'evening' person."

${ }^{2}$ Scale for self-rated health includes: poor, fair, good, and excellent. 
Table 3. Summary-level MR analyses relating educational attainment and BMI to shift work status ${ }^{1}$

\begin{tabular}{cccccccr}
\hline \multicolumn{1}{c}{ Inverse-variance } \\
weighted
\end{tabular}

${ }^{1} \mathrm{n}=17,259$ cases of 'frequent shift work' / 159,903 controls

adj.: adjusted for; OR: odds ratio; CI: confidence interval; MVMR: multivariable MR 
medRxiv preprint doi: https://doi.org/10.1101/2020.03.10.20032698; this version posted March 19, 2020. The copyright holder for this preprint (which was not certified by peer review) is the author/funder, who has granted medRxiv a license to display the preprint in perpetuity.

It is made available under a CC-BY-NC-ND 4.0 International license .

Figure 1. Causal diagram by which shift work may influence cardiometabolic risk. Shift may directly cardiometabolic risk, however selection into shift work through cardiometabolic risk factors or disease may also induce or modify relationships.

Figure 2. Analysis workflow.

Figure 3. Associations of genetic instruments for cardiometabolic traits with current overall shift work ${ }^{1}$. The effect sizes correspond to a unit change in the GRS, or to an additional effect allele for the single-SNP instruments.

${ }^{1} \mathrm{n}_{\text {total }}=190,573 ; \mathrm{n}_{\text {controls }}=159,903, \mathrm{n}_{\text {some shift work }}=13,411, \mathrm{n}_{\text {freqnent shift work }}=17,259$

BMI: body mass index; CAD: coronary artery disease; CI: confidence interval; GRS: genetic risk score; SNP: single nucleotide polymorphism; DM: diabetes mellitus; OR: odds ratio; WHR: waist-to-hip ratio adjusted for BMI

Figure 4. Associations of genetic instruments for cardiometabolic risk factors and disease with current night-shift work ${ }^{1}$. The effect sizes correspond to a unit change in the GRS, or to an additional effect allele for the single-SNP instruments.

${ }^{1}$ ntotal $\left.=190,573, \mathrm{n}_{\text {controls }}=159,903, \mathrm{n}_{\text {non-night shift }}=15,288, \mathrm{n}_{\text {some night shift }}=8,726 ; \mathrm{n}_{\text {frequent night sfhit }}=6,629\right)$

BMI: body mass index; CAD: coronary artery disease; CI: confidence interval; GRS: genetic risk score; SNP: single nucleotide polymorphism; DM: diabetes mellitus; WHR: waist-to-hip ratio adjusted for BMI 


\section{Selection via mediators}

Cardiometabolic risk factors, such as:

BMI, WHR, education, cardiometabolic disease liability, smoking heaviness,

Job tolerability

Work-related skills

Chronotype

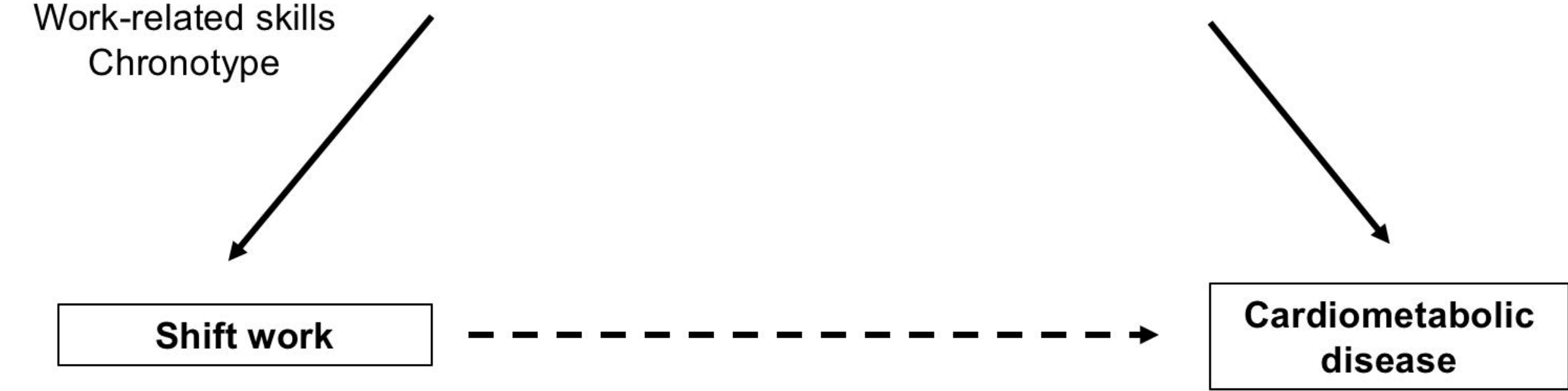

alcohol consumption, LDL 


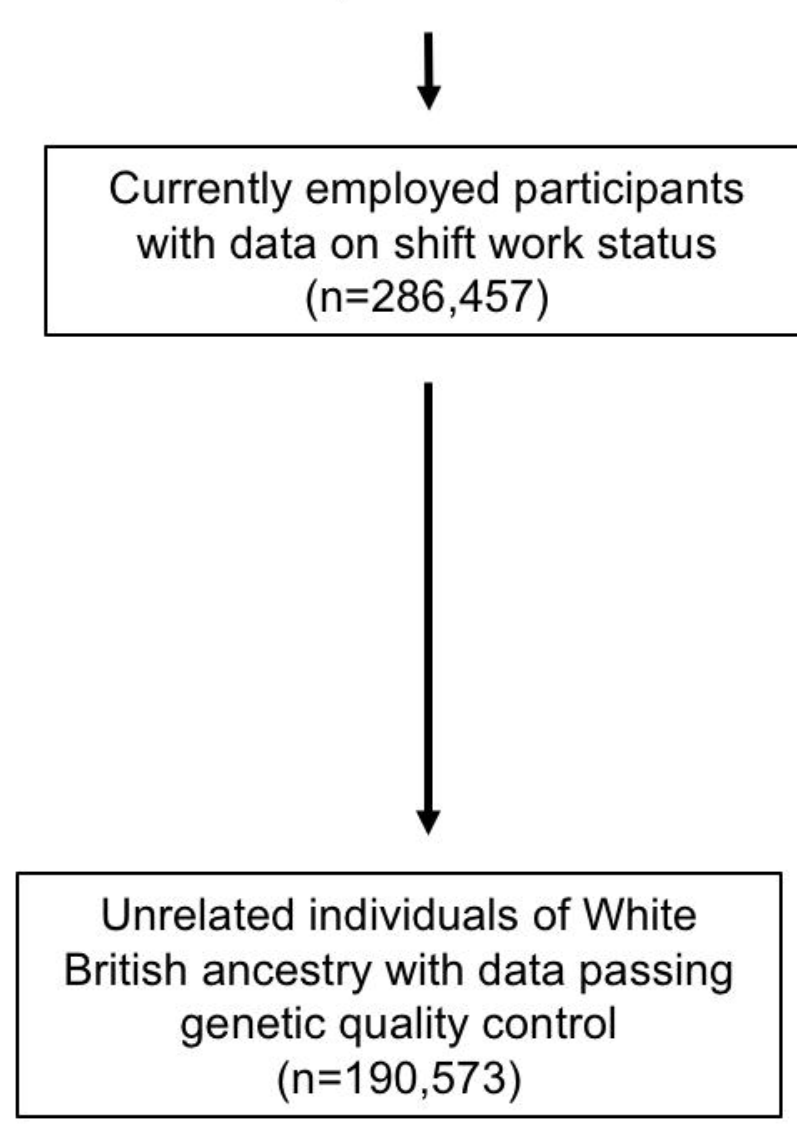

Primary analysis: Current shift work

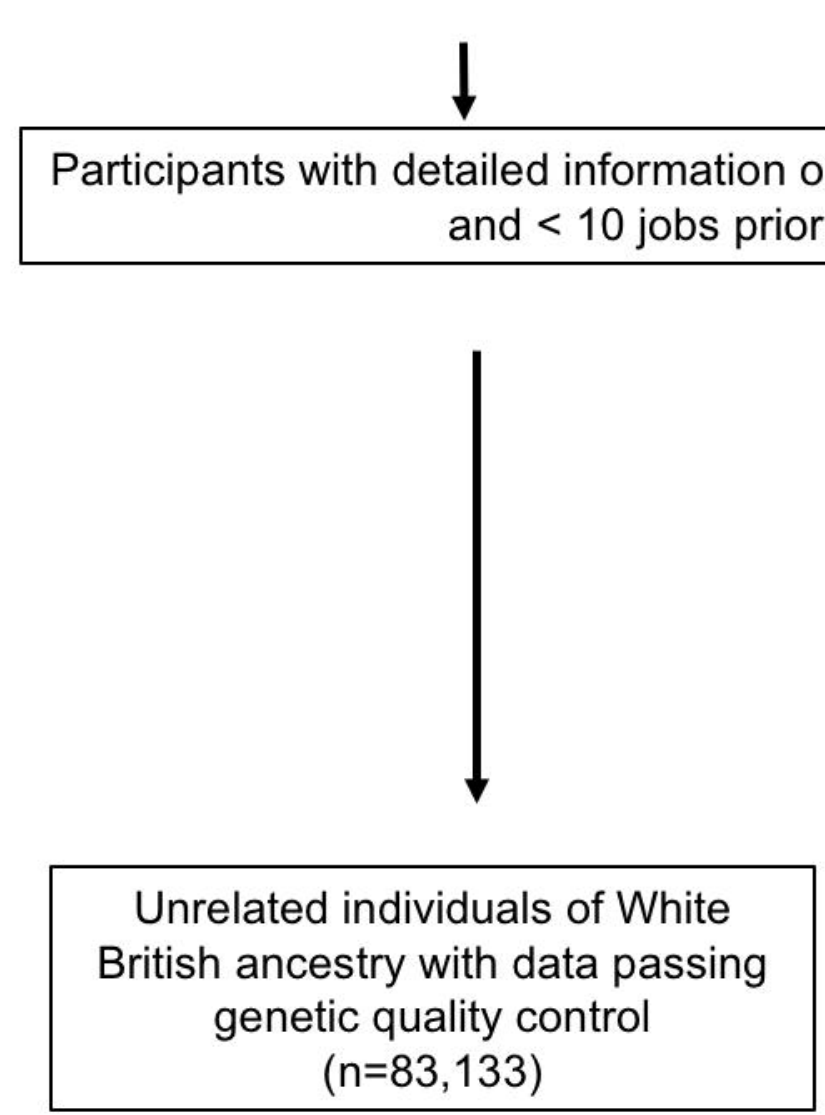

\section{Secondary analysis:} Lifetime history of shift work
Participants who have worked at least one shift work job $(n=33,043)$

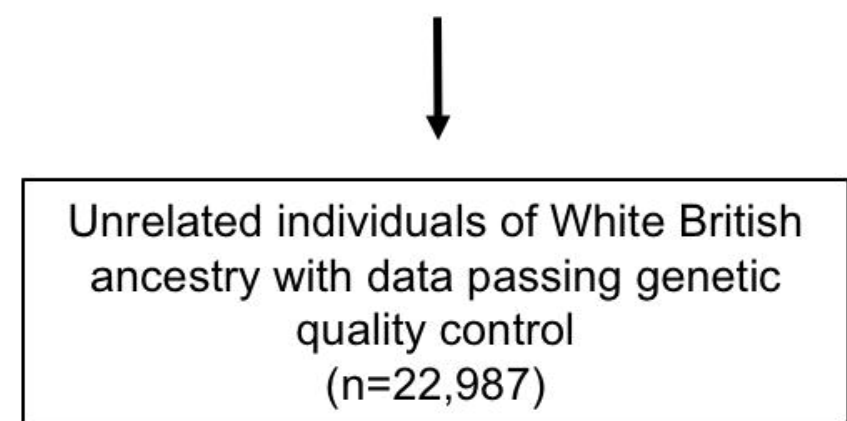

Secondary analysis: History of quitting shift work 


\section{Exposure}

n SNPs

OR $[95 \% \mathrm{Cl}]$

Education

Employed, not shift worker

Some shift work

Frequent shift work

Alcohol consumption

Employed, not shift worker

Some shift work

Frequent shift work

Smoking heaviness

Employed, not shift worker

Some shift work

Frequent shift work

BMI

Employed, not shift worker

Some shift work

Frequent shift work

WHRadjBMI

Employed, not shift worker

Some shift work

Frequent shift work

LDL

Employed, not shift worker

Some shift work

Frequent shift work

Type 2 diabetes

Employed, not shift worker

Some shift work

Frequent shift work

Coronary artery disease

Employed, not shift worker

Some shift work

Frequent shift work
68

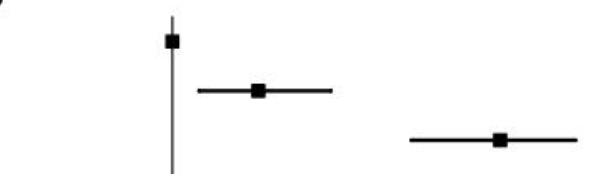

1.32 [1.10-1.59]

$2.22[1.89-2.63] \quad<2 \mathrm{E}-16$

1
$1.01[0.92-1.01]$
$0.98[0.91-1.06]$

Ref

0.87

$0.98[0.91-1.06] \quad 0.6$

$0.98[0.95-1.02]$

Ref

$1.02[0.99-1.06]$

0.17

91

1

1.21 [1.08-1.35]

1.25 [1.14-1.38]

Ref

9.20E-04

47

1

$0.98[0.84-1.15]$

1.06 [0.92-1.22]

Ref

0.81

0.4

190

103

57

$\begin{array}{cc}1 & \text { Ref } \\ 0.97[0.95-1.01] & 0.12 \\ 0.99[0.96-1.02] & 0.52\end{array}$

1

$1.01[0.99-1.04] \quad 0.39$

$1.01[0.99-1.03] \quad 0.31$

$0.99[0.96-1.02]$

Ref

$1.01[0.98-1.04] \quad 0.46$ 


\section{Exposure}

Education

Employed, not shift worker Shift worker, no nights

Some night shifts

Frequent night shifts

Alcohol consumption

Employed, not shift worke

Shift worker, no nights

Some night shifts

Frequent night shifts

Smoking heaviness

Employed, not shift worke

Shift worker, no nights

Some night shifts

Frequent night shifts

$\mathrm{BMI}$

Employed, not shift worker Shift worker, no nights

Some night shifts

Frequent night shifts

WHRadjBMI

Employed, not shift worker

Shift worker, no nights

Some night shifts

LDL

Employed, not shift worker

Shift worker, no nights

Some night shifts

Frequent night shifts

Type 2 diabetes

Employed, not shift worker

Shift worker, no nights

Some night shifts

Frequent night shifts

Coronary artery disease

Employed, not shift worker

Shift worker, no nights

Some night shifts

Frequent night shifts
68

1

91

47

190

103

57

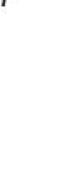

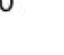

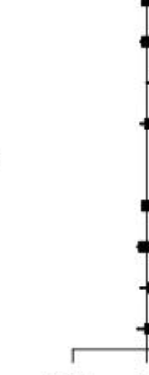

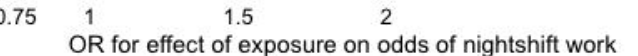

$\begin{array}{cc}1 & \text { Ref } \\ 1.43[1.20-1.69] & 4.17 \mathrm{E}-05\end{array}$

$1.75[1.39-2.17] \quad 3.59 \mathrm{E}-07$

$2.94[2.27-3.85] \quad<2 E-16$

$\begin{array}{cc}1 & \text { Ref } \\ 0.95[0.88-1.03] & 0.24\end{array}$

$1.07[0.97-1.19] \quad 0.19$

$0.98[0.86-1.11] \quad 0.71$

$\begin{array}{cc}1 & \text { Ref } \\ 1.01[0.97-1.05] & 0.64\end{array}$

$1.00[0.96-1.05] \quad 0.85$

$1.00[0.95-1.05] \quad 0.96$

1 Ref

1.16 [1.05-1.29] $5.00 \mathrm{E}-03$

$1.21[1.06-1.38] \quad 6.20 \mathrm{E}-03$

1.44 [1.23-1.68] $4.00 \mathrm{E}-06$

$\begin{array}{cc}1 & \text { Ref } \\ 1.05[0.91-1.21] & 0.52\end{array}$

$0.99[0.82-1.20] \quad 0.91$

$1.01[0.82-1.25] \quad 0.92$

$\begin{array}{cc}1 & \text { Ref } \\ 0.97[0.94-0.99] & 0.02\end{array}$

$1.02[0.98-1.06]-0.3$

$\begin{array}{cc}1.02[0.98-1.06] & 0.3 \\ 0.98[0.94-1.02] & 0.33\end{array}$

$\begin{array}{cc}1 & \text { Ref }\end{array}$

$1.00[0.98-1.02] \quad 0.91$

$\begin{array}{ll}1.03[1.00-1.06] & 0.08 \\ 1.01[0.98-1.05] & 0.42\end{array}$

$\begin{array}{cc}1 & \text { Ref }\end{array}$

$1.02[0.98-1.05]-0.55$

$\begin{array}{ll}1.02[0.98-1.05] & 0.38 \\ 1.01[0.97-1.05] & 0.82\end{array}$ 